\title{
REGIONAL EQUITY GOALS AND CHINESE DEVELOPMENT POLICY\#
}

\author{
DanN Milne*
}

It is now generally recognized that economic disparities between regions within a country are a universal phenomenon. In his early study of the economic development process, Hirschman concluded that, "interregional inequality of growth is an inevitable concomitant and condition of growth itself." ${ }^{1}$ In a subsequent article, Williamson investigated the empirical nature of this regional inequality. ${ }^{2}$ Using time series data on regional income per capita for ten countries and crosssectional data for twenty-four, Williamson finds that regional disparities follow an inverted U-shaped path as national growth progresses, with disparities widening in developing countries and eventually narrowing in maturing nations.

Both Williamson and Hirschman indicate that one of the factors that can lead to the narrowing of regional disparities is government response to the inequality problem with a regional development program. But as Robock correctly points out, the ability of government to reduce disparities varies with the country's stage of development. $\mathrm{He}$ notes the greater costs of reducing disparities at an early stage of development. ${ }^{3}$ These higher national growth-regional equity trade-off costs seemingly preclude a reduction of disparities in less developed countries.

Benjamin Chinitz has attempted to identify situations in which development policies to reduce regional inequality, compatible with national growth efforts, would be most effective. Chinitz discusses "investment opportunities which are specific to a region which are not substitutes for projects in other regions," the development of entrepreneurial talent, and infrastructure investments. ${ }^{4}$ Others have provided similar theoretical recipes ${ }^{5}$ but there have been few examples of successful development policies on which to test these theoretical judgments. While we have several examples of mature nations experiencing difficulties in reducing their disparities, ${ }^{6}$ we have few examples of successful programs to reduce regional inequality, particularly among the less developed nations.

China provides an example of a successful regional development effort. Over the past thirty years the Chinese have succeeded in narrowing economic disparities between regions, despite being, as Robock

\#Many of the elements of this paper come from extensive conversations with Professor Xu Ming of the Chinese Academy of Social Sciences, Beijing during 1979-80. I also wish to acknowledge the helpful comments of Satish Raichur and two referees of this journal.

*Assistant Professor, Department of Economics, University of Denver, Denver, Colorado 80208. 
points out, in a disadvantageous situation. Because of its success, the Chinese regional development effort, and particularly the ingredients of that effort, merit particular attention.

The Chinese government has consistently followed a policy emphasizing greater regional equity. The First Five-Year Plan (1953-1957) contains a general statement on regional policy:

We shall locate the productive forces of industry in different parts of the country in such a way that they will be close to producing areas of new materials and fuel and also to consumer markets. They will also satisfy the requirements for the strengthening of national security, lead to the gradual improvement of the irrational location pattern, and elevate the economic level of the backward areas. In the establishment of industrial areas, we shall, first of all, utilize, reconstruct, and transform the existing industrial bases so as to avoid over-concentration of enterprises and to bring about a suitable measure of decentralization. ${ }^{7}$

Promoting regional equity, emphasizing national decentralization and development of lagging regions, is an integral part of national economic policy.

Regional policy in China should be viewed similarly to anti-inflation policy in the United States. Neither can be completely separated from national economic policy, but they both involve important goals to those societies and merit discussion on their own. Because of the consistent focus on a regional equity goal, those elements of national economic policy promoting regional convergence will be labeled regional policy in this discussion.

Some important ingredients of Chinese regional policy are: a redistribution of intergovernmental revenues to lagging regions, mechanisms to speed adoption of innovations in lagging regions, a sector strategy that promotes rural development, the development of underemployed resources including: movement of unemployed workers to lagging regions, and taking advantage of external economies-particularly from the skilled labor pool. The importance of each element has varied over time within China and no effort will be made here to determine the relative contribution of each to regional convergence. This paper will present evidence of the regional convergence phenomenon, describe the regional development framework, delineate the specific regional policies that have contributed to regional convergence in China, and discuss their applicability in other developing countries.

\section{Inequality and Convergence}

One of the major economic realities that faced the newly formed People's Republic of China was the extreme dualism of their economy. Industrial and agricultural production was concentrated in the coastal 
regions, particularly the Northeast. This was seen as a result of the long-term domination of the Chinese economy by foreign powers. Charles Roll and Kung-Chia Yeh report that in 1952, with 39 per cent of the population, the 7 coastal provinces ${ }^{8}$ produced 61 per cent of the industrial output. The 19 remaining inland provinces or regions, with 61 per cent of the population produced 31.6 per cent of the industrial output. Moreover, agricultural production was heavily concentrated in these same coastal provinces. With 11.4 per cent of the national land mass, their cultivated land was 33 per cent of the total cultivated area in China. ${ }^{9}$ The probable widening of these disparities as development progressed was especially problematical to a socialist government founded on the principles of redistribution with much of its political base among the rural masses. Thus, the level of political commitment to the lagging rural areas was quite high and its economic development strategy has evolved with a substantial effort focused on removing regional disparities.

TABLE 1

GROSS VALUE OF INDUSTRIAL OUTPUT, BY PROVINCE (Million 1957 Yuan)

\begin{tabular}{|c|c|c|c|c|c|c|c|}
\hline $\begin{array}{l}\text { Per Cent } \\
\text { Province }\end{array}$ & \multicolumn{2}{|c|}{$1949+$} & \multicolumn{2}{|c|}{$1957+$} & \multicolumn{2}{|c|}{$1974+$} & $\begin{array}{c}\text { Change } \\
1957-74\end{array}$ \\
\hline \multicolumn{8}{|l|}{ Northeast } \\
\hline Heilongjiang & 778 & .0492 & 3,641 & .0522 & 15,785 & .0458 & 334 \\
\hline Jilin & 396 & .0250 & 2,155 & .0309 & 9,378 & .0272 & 335 \\
\hline Liaoning & 1,323 & .0836 & 10,078 & .1444 & 40,727 & .1181 & 304 \\
\hline \multicolumn{8}{|l|}{ North } \\
\hline$\overline{\text { Beijing }}$ & 170 & .0107 & 2,100 & .0301 & 18,569 & .0538 & 784 \\
\hline Tianjin & 741 & .0468 & 3,911 & .0560 & 17,524 & .0508 & 348 \\
\hline Hebei & 970 & .0613 & 2,519 & .0361 & 22,648 & .0657 & 799 \\
\hline Shanxi & 218 & .0138 & 1,645 & .0236 & 6,264 & .0182 & 281 \\
\hline Nei Monggol A.R. & 82 & .0052 & 631 & .0090 & 6,018 & .0174 & 854 \\
\hline \multicolumn{8}{|l|}{ East } \\
\hline Shanghai & 3,337 & .2109 & 11,402 & .1634 & 52,892 & .1533 & 364 \\
\hline Shandong & 945 & .0597 & 3,640 & .0522 & 20,374 & .0591 & 460 \\
\hline Jiangsu & 1,648 & .1042 & 4,124 & .0591 & 23,435 & .0679 & 468 \\
\hline Zhejiang & 570 & .0360 & 2,132 & .0305 & 7,805 & .0226 & 266 \\
\hline Anhui & 369 & .0233 & 1,348 & .0193 & 6,149 & .0178 & 356 \\
\hline Jiangxi & 215 & .0136 & 1,100 & .0158 & 5,242 & .0152 & 377 \\
\hline Fujian & 267 & .0169 & 1,100 & .0158 & 4,325 & .0125 & 293 \\
\hline \multicolumn{8}{|l|}{ Central-South } \\
\hline Henan & 228 & .0144 & 1,560 & .0224 & 11,323 & .0328 & 626 \\
\hline Hubei & 547 & .0346 & 2,514 & .0360 & 9,238 & .0268 & 267 \\
\hline Hunnan & 318 & .0200 & 1,634 & .0234 & 8,284 & .0240 & 407 \\
\hline Guangxi A.R. & 194 & .0123 & 717 & .0103 & 4,528 & .0131 & 532 \\
\hline Guangdong & 865 & .0547 & 3,570 & .0511 & 17,195 & .0498 & 382 \\
\hline
\end{tabular}




$\begin{array}{lrrrrrrr}\text { Northwest } & & & & & & & \\ \text { Gansu } & 126 & .0080 & 695 & .0100 & 6,769 & .0196 & 873 \\ \text { Shaanxi } & 305 & .0193 & 1,134 & .0162 & 6,517 & .0189 & 475 \\ \text { Ningxia A.R. } & 5 & .0003 & 23 & .0003 & 359 & .0010 & 1461 \\ \text { Quinghai } & 19 & .0012 & 117 & .0017 & 1,259 & .0036 & 976 \\ \text { Xinjiang A.R. } & 85 & .0054 & 465 & .0067 & 1,861 & .0054 & 300 \\ & & & & & & & \\ \text { Southwest } & & & & & & & \\ \text { Sichuan } & 150 & .0474 & 4,283 & .0614 & 13,852 & .0402 & 223 \\ \text { Yunnan } & 180 & .0114 & 989 & .0142 & 3,398 & .0099 & 243 \\ \text { Guizhou } & 170 & .0107 & 562 & .0081 & 3,158 & .0092 & 462 \\ \text { Xizang A.R. } & 0 & .0000 & 9 & .0001 & 89 & .0003 & 888 \\ & & & & & & & \\ \text { Totals } & 15,821 & .9999 * & 69,798 & 1.0003 * & 344,965 & 1.0000 & 394\end{array}$

Source: Robert M. Field, Nicholas R. Lardy and John Phillip Emerson, China: Gross Value of Industrial Output, 1965-77, (National Foreign Assessment Center Research Paper, Central Intelligence Agency, Washington, D.C.), June, 1978, p. 5.

${ }^{+}$The years 1949, 1957, and 1974 were selected because those were the years with complete data.

*Totals may not sum to one because of rounding errors.

A.R.: Autonomous Region

Over time, the considerable inequality between regions has been reduced. Table 1 presents data on gross industurial product by province. ${ }^{10}$ The value of industrial production in 1949 ranged from zero in Xizang to 3,337 million yuan in Shanghai with a coefficient of variation of 1.21. The 1957 figures range from 9 to 3,911 million yuan with a coefficient of variation of 1.080 . The 1974 industrial production data range from 89 to 52,892 million yuan with a coefficient of variation of .981. The dispersion about the mean has decreased. Regional inequality has decreased in an absolute sense.

The less developed provinces grew at a significantly higher rate than the others. The 9 least developed provinces of $1957^{11}$ grew at an average rate of 732 per cent over the 1957-1974 period. This was almost double the national average growth rate. The 20 more developed provinces grew at an average of 407 per cent over the same period.

The convergence of industrial production between provinces is also seen by looking at the production shares of each province. The share of industrial production of the 9 least developed provinces increased from 5.4 per cent in 1949 to 6.0 per cent in 1957 to 7.95 per cent in 1974 . While this increase was not statistically significant, the data do indicate a tendency toward convergence. According to Williamson, countries at China's level of development should be experiencing increased regional inequality. ${ }^{12}$ China is not. This reflects the regional policies of the central government. 


\section{Regional Development Framework}

Before discussing those policies we must understand the main features of the framework in which Chinese regional policy operates. These are central planning (which is becoming more decentralized), autonomous regions, and the rural commune.

Regional policy, as an integral part of national policy, is made by the Party Central Committee and the State Planning Commission. The Central Committee plays an advisory role and gives the state plan most of its political content. The State Planning Commission, following Party directives, is charged with formulation of production, investment and distribution targets and establishing the prices for basic commodities. This constitutes the state plan. The State Economic Commission is responsible for implementation of the plan.

The plan sets quantitative targets for the provincial level. The province then is responsible for allocating tasks to the county level. The county sets targets for its communes, communes set targets for their production brigades and the brigade allocates tasks to its subordinate work teams (firm equivalents).

The central authorities directly control the state enterprises which occupy a dominant position in the economy. Notable examples are the steel and petroleum industries. Communes, production brigades and production teams are not state controlled. Rather, they are collectively owned operations. The planning and resource allocation for these units are done at the local level.

The national planning process will gain greater regional content in the near future. Xu Ming and Xue Baoding reveal the intention. "We shall also make regional economic plans on a national scale so as to make the best use of everything everywhere. ... " ${ }_{13}$ This continued decentralization of planning would permit a coordination of investment and resource allocation not currently present.

The autonomous region is one of the major structures for regional programming. The 5 main autonomous regions, 29 autonomous prefectures and 69 autonomous counties (See Map 1) are primarily populated by members of the 55 non-Han minorities. These 50 million minority people inhabit almost 50 per cent of China's land mass.

In a major speech to the Central Committee of the Chinese Communist Party (1956) Chairman Mao Zedong emphasized the state commitment to improving the extremely depressed living conditions of the non-Han minorities. ${ }^{14}$ This commitment continues to be an important part of national policy.

Minority areas receive special assistance from the national government. This aid includes special investment priority, substantial financial subsidies for local government expenditures, grants of industrial equipment and agricultural machinery, and administrative and technical personnel. State trading teams serve these regions, as they do all of the countryside, buying local production and supplying a wide variety of goods at state administered prices. Health care services, 


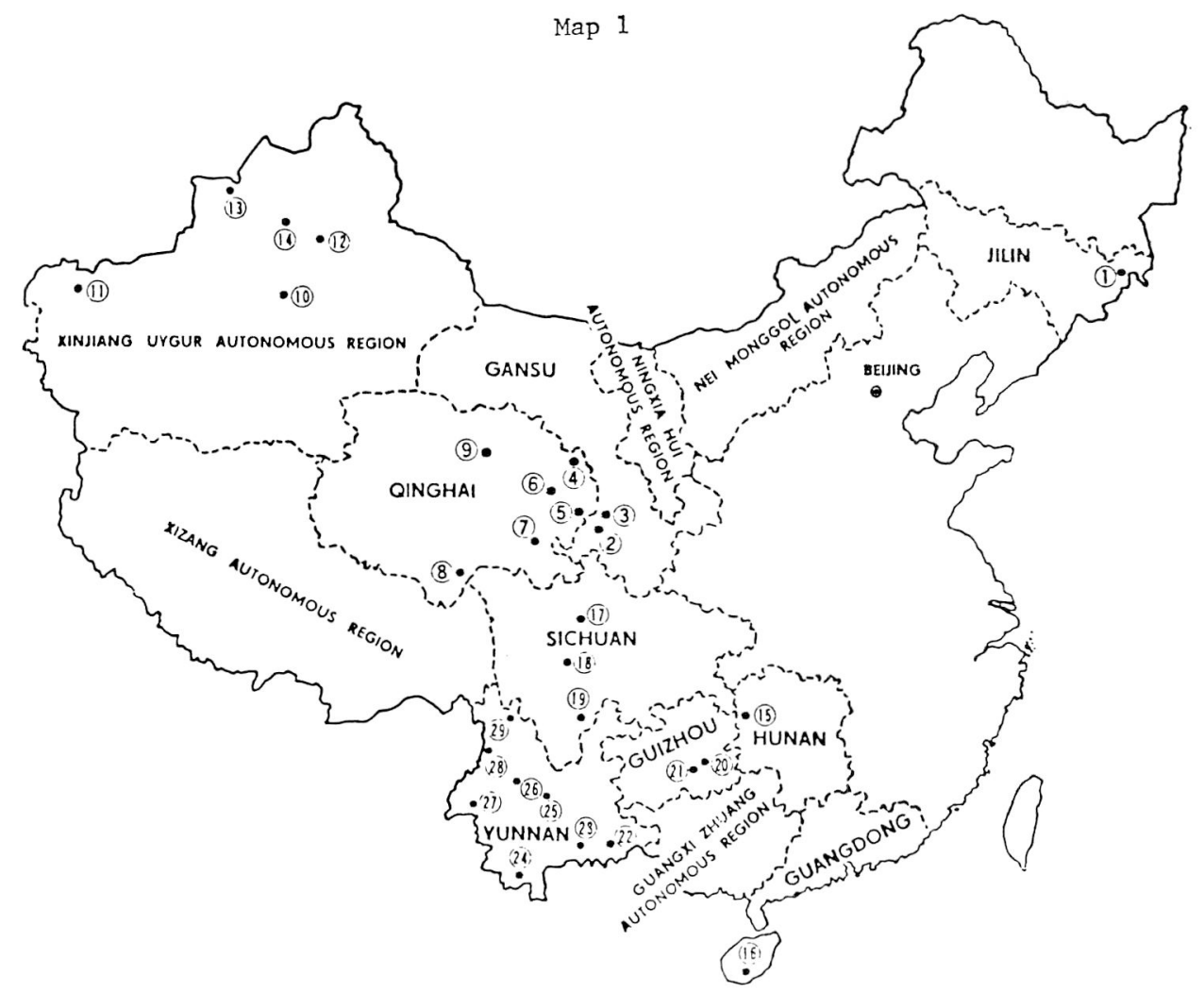

1. Yanbian Korean Autonomous Prefecture

2. Gannan Tibetan Autonomous Prefecture

3. Linxia Husi Autonomous Prefecture

4. Haibei Tibetan Autonomous Prefecture

5. Huangnan Tibetan Autonomous Prefecture

6. Hainan Tibetan Autonomous Prefecture

7. Guoluo Tibetan Autonomous Prefecture

8. Yushu Tibetan Autonomous Prefecture

9. Haixi Mongolian, Tibetan, Kazakh Autonomous Prefecture

10. Bayingolin Mongolian Autonomous Prefecture

11. Kizilsu Khalkhas Autonomous Prefecture

12. Changji Hui Autonomous Prefecture

13. Bortala Mongolian Autonomous Prefecture

14. Ili Kazakh Autonomous Prefecture
15. Xiangxi Tujia, Miao Autonomous Prefecture

16. Hainan Li, Miao Autonomous Prefecture

17. Aba (Ngawa) Tibetan Autonomous Prefecture

18. Garze Tibetan Autonomous Prefecture

19. Liangshan Yi Autonomous Prefecture

20. Qiandongnan Miao, Dong Autonomous Prefecture

21. Qiannan Bouyei, Miao Autonomous Prefecture

22. Wenshan Zhuang, Miao Autonomous Prefecture

23. Honghe Hani, Yi Autonomous Prefecture

24. Xishuangbanna Dai Autonomous Prefecture

25. Chuxiong Yi Autonomous Prefecture

26. Dali Bai Autonomous Prefecture

27. Dehong Dai, Jingpo Autonomous Prefecture

28. Nujiang Lisu Autonomous Prefecture

29. Degen Tibetan Autonomous Prefecture

Source: Beijing Reveiw, No. 25, June 22, 1979. 
primarily in the form of "barefoot doctors" (health care paraprofessionals) and mobile medical teams, are provided.

A special agency has recently been established to advance economic development in minority regions. Composed of the State Capital Construction Commission, the State Economic Commission and the State Nationalities Affairs Commissions, the new agency will coordinate the substantially increased capital construction allocations and subsidies for minority areas. ${ }^{15}$ The establishment of this new coordinating agency signals the increased importance of this aspect of regional policy,

Other regions marked for special consideration are the Provinces of Hunnan and Kwangsi. Among the least developed, these provinces were the starting points of The Long March in the War of Liberation. They receive the same special assistance as the autonomous regions.

Substantial state funds flow to the less developed regions and provinces. The amount of interprovincial income redistribution is quite large. Lardy reports that the "more developed provinces give up a disproportionately large share of the revenues they collect while poorer provinces retain all of their revenues and also receive additional subsidies from the center." 16 The more developed provinces of Jiangsu, Liaoning and Shanghai remit from 70 to 90 per cent respectively of their revenues to the central government while 5 autonomous regions retain all of their revenues. The autonomous regions of Xizang, Xinjiang and Ningxia have received revenue grants amounting to $30-50$ per cent of each province's total expenditures each year since $1960 .{ }^{17}$ Over a period of twenty to twenty-five years the central government has used its fiscal system to redistribute resources for productive investments from developed to less developed regions.

Another important institutional feature of China's development is the commune. Agricultural people's communes should be regarded ". . . as an attempt to create territorial integration of all the activities of the populations concerned. The area concept as the basis of organization led towards the integration of the existing agricultural, social, political, educational, medical and other activities within the limited territory of the commune."18

Communes were established as the basic administrative unit at the local level at the beginning of the Great Leap Forward in 1958. The commune is responsible for procuring grain, collecting taxes, formulating specific production plans for its subordinate units (brigades and work teams) and managing local industries producing for local consumption. ${ }^{19}$

The integrated functional relations of production and marketing in communes and their relationships to higher county and national levels recall the marketing areas of Christaller and Lösch. ${ }^{20}$ The spatial organization of the adminstrative function and the marketing functions are coincident in the commune. As we shall see later, the commune became the focus of rural industrialization efforts.

Similar spatial organization developments are also occurring in urban areas. Urban units in which production units are integrated with 
residences and service activities are becoming a popular form of spatial organization. The formation of urban communes, a merger between production and residential organizations, has eliminated the former conflict between the two. New industrial plants are being designed with housing areas attached. Some authors believe this consolidation of living and working space in the same small area to be the organizational pattern of the future in urban areas. ${ }^{21}$

\section{Problems and Policies}

Chinese planners were confronted with problems of widening ruralurban disparities and urban unemployment caused by rural-urban migration in excess of employment generation in the cities. ${ }^{22}$ Another problem was the difficulty of transferring new technologies and innovations to rural areas. We now discuss Chinese policy solutions to these problems.

Chinese regional development policy has three main components. These are rural industralization, rustication (the movement of young people to the countryside), and a program to transfer technology. These policies, particularly rural industrialization, base their evolution in Chinese pragmatism.

Early emphasis on the development of heavy industry (1953-1957) was the cause of many problems for Chinese planners. ${ }^{23}$ China's dependence on capital equipment and technicians from Russia was increasing, their balance of payments was worsening, and economic planning and allocation was becoming more centralized in the hands of a few bureaucrats. In addition, polarization was drawing people from rural areas-decreasing food production and increasing requirements for additional social overhead capital. These are the classic problems faced by Third World nations attempting to modernize. The Chinese sought solutions to these problems with a pragmatic, nontraditional development strategy.

The First Five Year Plan (1953-1957), following the Soviet economic model, placed its emphasis on heavy industry located in a few urban areas. Kang Chao states that "virtually all the new construction projects for industry in the First Five Year Plan were distributed in 120 cities and a majority of the large projects were clustered in 18 cities. ${ }^{\prime_{24}}$

This industrial concentration policy placed severe strains on housing in urban areas. The government was forced to shift investment funds from directly productive activity to expenditures for urban infrastructure and housing with a resulting loss in potential growth in output. The migration flow of people exceeded the absorptive capacity of the urban industries and unemployment levels began to grow.

At the same time it became clear to Chinese planners that one of the causes of agricultural stagnation was the removal of agriculture workers to urban industries. Strains were also put on an underdeveloped transportation system to carry the produce to urban markets. 
A program of rural industrialization to modernize agricultural production became the primary alternative to break the constraints on continued rapid industrialization. Mechanization of agriculture could then improve agricultural productivity enough to sustain a growing urban industrial workforce.

The rural industrialization program emphasizes the development of "five small industries": iron and steel, cement, chemical fertilizer, energy (coal mining and electrical generation) and machinery. Agricultural machinery manufacturing and repair is a particulary important sector of rural industry. Most agricultural machinery manufacturing occurs at the county level, while repairs are done at the lower commune and worker brigade levels. The processing of agricultural products also occurs primarily at the commune and brigade levels. This includes flour milling, oil processing, cotton ginning, and yarn spinning. ${ }^{25}$

The program conforms closely with several elements of Maoist ideology. The change can clearly be associated with Maoist antipathy to bureaucratization. ${ }^{26}$ Small scale industries in rural areas would not require the extensive, top-heavy planning and allocation structure characteristic of a centrally planned socialist economy. Additionally, rural industrialzation met the problem of rural-urban balance directly. Equality in the relationship between rural and urban peoples was a fundamental tenet of Maoist doctrine.

Rural industrialization brings development directly to the rural masses. The motivational implications for the masses of the close relationship between income generation and consumption of consumer goods is important. Reaping the immediate rewards of their own production efforts would provide incentives for further efforts. Further, local production would enable producers to keep in touch with the needs of the consumer in order to prevent waste. ${ }^{27}$

This program is not merely an equity adjunct to the overall development process. It plays a key role in that process. Light industry in rural areas promotes capital accummulation. Increased mechanization of agriculture and the resultant agricultural development create rising agricultural incomes which can support light industry. Local production provides consumer goods at prices which permit considerable capital accumulation. Profits or surplus from light industry are then used to finance heavy industry development in rural areas. ${ }^{28}$

Rural industrialization not only accumulates capital but the small scale nature of the industries allows capital saving also, i.e. it requires less capital for a given increase in output. This less capital-intensive form of industrial growth is better suited to existing factor proportions. This program creates a cumulative growth relationship with agriculture. The focus of the program is on supporting increases in agricultural productivity. The resultant rising incomes generates an expanding market for the consumer goods also produced by industry at the local level. The rural industrialization effort emphasizes those 
activities with high backward linkages to agriculture or high forward linkages to the local market. Additionally, the lower wages paid in the rural industrial sector will help control the rate of increase of wages in the more modern, urban industries. ${ }^{29}$

The second major development problem addressed by Chinese regional policy was that of labor absorption in urban areas. In spite of long-term, extensive efforts at population control, urban working-age populations continued to grow faster than urban employment opportunities. The major policy response to this problem of structural unemployment was rustication. Rustication is the practice of sending graduates of urban secondary schools and other youths to the countryside and frontier areas. These youths are considered to be surplus labor because they have not been accepted by higher education institutions or have not been assigned a job in the cities. The rusticated youths are expected to settle permanently in rural villages and become productive members of their communities.

Idealism motivated many youths to volunteer for rustication. Others were subjected to various pressures and threats, such as peer group pressure, pressures from political cadres, lack of a job assignment, threat of a worse job alternative, and threats of a cut-off of food ration coupons. These were strong incentives to accept the rustication assignment. $^{30}$

After a lapse during the Cultural Revolution, the rustication program was renewed with increased intensity in 1968. "Estimates of the total number of rusticated urban educated youths vary from 10 to 15 million. Any figure within this range of magnitude would definitely rank this population movement as one of the greatest migrations in history within the time span of two to three years." 31

The youths worked in the fields, on water irrigation and conservation projects, or in commune workshops. A few obtained positions as teachers, accountants, barefoot doctors, and village cadres. On the whole, the rusticated youths were incorporated into the village economy at average occupational positions-primarily as manual laborers.

The economic rationale for rustication is relatively simple. Urban industrial employment could not grow fast enough to accomodate new entrants to the labor force, thus creating serious unemployment problems. Unemployment or underemployment in the cities and its politically dysfunctional consequences are avoided by rustication. Moreover, the productivity of rusticated workers is increased by sending them to areas with opportunities for employment. The productive potential of disguised unemployment is tapped. Furthermore, increases in urban populations require significant social overhead capital investments in transportation, sanitation and housing. Such investments in rural areas are much more modest and are mostly shifted to the individuals themselves. This frees state investment resources for more directly productive investment. 
Another objective served by rustication is that of transferring knowledge and technical skills to rural communities. Most rusticated youths are relatively well educated high school graduates and can bring new knowledge and technical skills with them. These abilities contribute to agricultural modernization and mechanization. The combination of technical information brought by the youths and the practical experience of the peasant results in a useful synthesis of traditional and modern techniques.

The Chinese no longer distribute their human resources in this manner. The rustication policy was virtually abandoned during the mid-1970's with relatively few youths now moving to the countryside. Rustication became inconsistent with the increasing emphasis on economic freedom and reliance on markets that evolved during the 1970's. The program exists on a strictly voluntary basis with the elements of compulsion and the force of political mobilization absent. Rusticated youths are now assigned to work on state farms or on specially designated collective farms.

Technology is an important element in the development process and is especially important to rural development because of the difficulties in bringing new technologies to rural areas. The diffusion of innovations normally occurs down the city size hierarchy reaching rural areas slowly and unevenly. Speeding cost saving or developmental innovations to rural areas in less developed countries faces several obstacles. The low level of literacy, the underdeveloped media, the lack of widespread extension services and varying local conditions make the transfer of technology at the local level difficult.

One important part of the Chinese technology diffusion structure has already been discussed. Rusticated youth from the major urban centers bring technical knowledge and an interest in and receptivity to new ideas with them to rural areas. Their level of literacy and previous exposure to innovations creates a pool of workers disposed to adopt new technologies presented to them. In the words of Pi-chao Chen, the rusticated youth play " . . . the role of catalysts in diffusing modern attitudes, skills and knowledge, and in setting up and operating modern social infrastructures in the rural villages, all in the interest of accelerating rural transformation."'32

Probably the most important mechanisms for technology dissemination are the series of linkages between firms at different geographic levels. Jon Sigurdson categorizes these linkages.

Links between county-run enterprises within the county:

(1) Transfer of skilled manpower; (2) training of manpower;

(3) transfer and delivery of equipment; and (4) learning the spirit of self-reliance - in order to economize on funds and equipment.

Links with county-run enterprises outside the county:

(1) Learning indigenous production technology; (2) learning how to make indigenous equipment; and (3) establishing 
cooperative relations for the future.

Links with higher level enterprises:

(1) Learning modern production technology; (2) obtaining ideas for modifying design; and (3) establishing a donorrecipient relationship, involving further training, on-thespot assistance and delivery of equipment. ${ }^{33}$

These linkages are the formal network for technology transfer. A county-run industry or commune will send technicians to large and more developed enterprises to learn about a particular process that the commune wants to adopt or improve. Workers can also be sent for training in new techniques or in the use of new machines. Conversely, technicians can be sent down from large scale enterprises to instruct smaller enterprises in a new production technology.

The higher level industries have a responsibility for supplying new technology to lower level enterprises. This is not the only means, however, of county-run enterprises receiving innovations. A great deal of horizontal diffusion of technology occurs at the county level. Technology received from above must often be adapted to local (county level) conditions. Enterprises that are particularly successful at doing this become "model" enterprises. Then technicians from near and far come to study their operations so that their county can establish similar enterprises on the same scale. The Chinese have developed a deep appreciation for the scale of enterprises and for adapting technologies to make them appropriate to that scale.

In general, Chinese regional policies focus primarily on entities that are at the county level or above. There are no policies designed to reduce inequities at the commune, brigade or production team level. A commune is allowed to retain all of the surplus it creates and to reinvest those profits in the commune. The current taxation system requires each production team (firm equivalent) to pay a five per cent tax on its agricultural and side-line production to the central government. Another five per cent goes to the brigade level for management services. The five per cent tax leaving the commune level is a proportional tax. A commune with superior resource endowments, soil fertility or access to urban markets can begin a cumulative growth process which soon causes its income level to diverge from the other communes. Over time this could create very visible problems of inequality. The differences in incomes are not yet very large-but the problem will grow.

Some form of progressive taxation imposed on the wealthier communes would narrow the income inequality between communes. The agricultural tax could easily be made progressive. But such a progressive tax might interfere with incentives. The present system allows the communes to retain almost all of the surplus that they create in order to provide the maximum incentives for local initiative and self-reliance. Diminishing the monetary rewards might interfere with the important development objective of encouraging local initiative. 
This is a dilemma between two conflicting development objectives that will not be resolved easily. The trade-off between national growth and inter-commune equity is currently quite small. For the time being, the pragmatic Chinese planners will continue to emphasize incentives at the local level and focus their redistributional efforts at the provincial level.

The important elements of Chinese regional policy are the substantial interprovincial transfer of governmental revenues, a development strategy emphasis on agricultural mechanization and small scale industry which places much development activity in rural areas, rustication of youths to prevent excessive urban unemployment, and an institutionalized system of cooperative arrangements to facilitate the transfer of technology at the local level.

\section{Potential Transferability of the Chinese Experience}

The Chinese success in reducing regional disparities raises the question of transferability. Can the Chinese regional development model or elements of it be successfully applied in other developing countries? The Chinese would react skeptically to such a question. There is no conception of a singular model of regional development applicable in all nations under all conditions. Rather the perception is that each nation should have a pragmatic strategy, evolving to meet the objective conditions at particular times.

Certainly Chinese planners would advocate rustication for other countries only if their objective conditions were suitable. The Chinese no longer find such a program appropriate for their own conditions. The level of social mobilization must be adequate and the policy must conform to the overall development strategy for such a policy to be effective.

There are, however, a number of lessons to be learned by developing countries, socialist and non-socialist alike, from the Chinese experience. The level of commitment to regional equality is quite strong primarily because the Chinese perceive regional economic growth as an important ingredient in equality and not something to be traded off against it. High social and economic returns are found in developing unemployed or underemployed resources in rural areas. A part of this commitment has taken the form of substantial redistribution of revenues to poorer provinces, not in the form of transfer payments but in the form of productive investments.

Another important element of regional policy has been the integrated program of agricultural mechanization. The lesson here is primarily one of how mechanization was carried out. Mechanization can in many cases displace workers and worsen inequality. The key was retaining the surplus generated from the process in rural areas by locating the machinery fabrication and repair facilities there and allowing the communes to retain (almost) all of the fruits of their increased productivity. This permits the cumulative growth process to occur in 
the rural area rather than in some other growth pole.

Finally, the mechanisms for technology transfer could be suitably employed elsewhere. While few nations possess the level of political mobilization necessary to send youths to the countryside, most currently send extension agents to rural areas to spread new technologies. Some modification of this arrangement might generate the successes of the Chinese experience. Skilled workers and supervisors from successful enterprises could be recruited to spread the technology to other (appropriate) locations at government expense. Also, the receiving unit might require modification. A non-household unit such as a producer cooperative may be a better vehicle. This institutional arrangement would expose more individuals to the new technology, provide a forum for discussion of refinements and develop management skills among the cooperative's members.

No attempt is made here to suggest direct transfer of the Chinese model, or parts of it, to other countries. But many of the elements, with minor modifications, could be transferred and the results appear promising.

FOOTNOTES

${ }^{1}$ Albert O. Hirschman, The Strategy of Economic Development, (New Haven, Yale University Press, 1958) p. 184.

${ }^{2} \mathrm{~J}$. G. Williamson, "Regional Inequality and the Process of National Development: A Description of the Patterns," Economic Development and Cultural Change, Vol. 13, (1965), pp. 3-45.

3 Stefan Robock, "Strategies for Regional Economic Development," Papers of the Regional Science Association, XVII (1966), p. 132.

4 Benjamin Chinitz, "Appropriate Goals for Regional Economic Policy," Urban Studies, (February, 1966), p. 3-6

'Harry Richardson, Regional Economic Growth, (MacMillan, London, 1973), p. 323.

6 See Niles Hansen, ed., Public Policy and Regional Economic Development, (Ballinger, Cambridge, Mass., 1974). Canada, p. 329; Spain, p. 243; Italy, p. 147; France, p. 36.

The First Five-Year Plan of the People's Republic of China, (People's Publishing House, Peking, 1955), pp. 31-33.

${ }^{8}$ The seven coastal provinces are: Liaoning, Hebei, Shandong, Jiangsu, Zheijiang, Fujian, and Guangdong.

${ }^{9}$ Charles Robert Roll, Jr., and Kung-Chia Yeh, "Balance in Coastal and Inland Industrial Development," in Joint Economic Committee, China: A Reassessment of the Economy. (U.S. Government Printing Office, Washington, D.C., 1975), p. 82 .

10 The ideal data, per capita income by province, are not available. Similarly, agricultural production or population data by province were not available. Since industry is the fastest growing sector, it should demonstrate the greatest variation and reflect government policy well.

"Nei Monggol, Guangxi, Ningxai, Xinjiang, Xizang, Gansu, Quinghai, Yunnan, and Guizhou. The first five are autonomous regions.

${ }^{12}$ J.G. Williamson, ibid.

${ }^{13}$ Xue Boading and Xu Ming, "China's Economic Modernization - Its Background and Prospects." Paper presented at the Denver Conference on Third World Development, June 20. 1979, pp. 19-20.
14 Mao Zedong, On the Ten Major Relationships, Foreign Language Press, Beijing, 1977.

${ }^{15}$ Beijing Review, No. 25, June 22, 1979.

${ }^{16}$ Nicholas R. Lardy, "Economic Planning in the People's Republic of China: Central-Provincial Fiscal Relations," in Joint Economic Committee, China: A Reassessment of the Economy, (U.S. Government Printing Office, Washington, D.C., 1975), p. 111.

${ }^{17}$ Ibid., pp. 111-112.

${ }^{18}$ Hans Schenk, "Concepts Behind Urban and Regional Planning In China," Tijdschrift voor Economische en Sociale Geografie, Vol. 65, No. 5 (1974), p. 384

${ }^{19}$ In spite of a challenge by the "Gang of Four" during the Cultural Revolution (1966-1968) to replace it with the brigade, the production team has remained as the basic production unit. Frederick Crook, "The Commune System in the People's Republic of China, 1963-74," in Joint Economic Committee, China: A Reassessment of the Economy, (U.S. Government Printing Office, Washington, D.C., 1975), p. 366

${ }^{\text {to }}$ An early discussion of these basic geographic units in the China context is found in G. William Skinner, "Marketing and Social Structure in Rural China," Journal of Asian Studies, November 1964, February 1965 and May 1965.

${ }^{21}$ Ibid., p. 387 and G. Towers, "City Planning in China," Journal of the Town Planning Institute, Vol. 59, 1973, pp. 125-127.

${ }^{22}$ Most of the rural-urban migration problem developed during the First Five Year Plan (1953-1957) with its emphasis on heavy industry development in the largest cities. Liu and Yeh estimate that urban male unemployment increased from seven million in 1952 to eleven million in 1957. Ta-Chung Liu and Kung-Chia Yeh, The Economy of the Chinese Mainland: $\mathrm{Na}$ tional Income and Economic Development, 1933-1959. (Princton University Press, Princeton, N.J., 1965), p. 102.

${ }^{23}$ The heavy industry emphasis was due to the influence of the Soviet development model.

${ }^{24}$ Kang Chao, "Industrialization of Urban Housing in Community China," Journal of Asian Studies, 1966, p. 383. 
${ }^{25}$ Ibid.

${ }^{26} \mathrm{Carl}$ Riskin, "Small Industry and the Chinese Model of Development," China Quarterly, April 1971.

${ }^{2}$ Ibid.

"John Sigurdson, "Rural Industry-A Traveller's View." China Quarterly, April-June 1972, p. 324.

${ }^{2}$ John Sigurdson, "Rural Industrialization in China," in Joint Economic Committee, China: A Reassessment of the Economy, (U.S. Government Printing Office, Washington, D.C., 1975), pp. 433-434.
${ }^{30} \mathrm{Pi}$-chao Chen, "Overurbanization, Rustication of UrbanEducated Youths, and Politics of Rural Transformation," Comparative Politics, April 1972, p. 367, and Jan S. Prybyla, "Hsai-Fang: The Economics and Politics of Rustication in China," Pacific Affairs, p. 163.

${ }^{3}$ Pi-chao Chen, ibid., p. 369.

${ }^{32} \mathrm{Pi}$-chao Chen, p. 378.

"Jon Sigurdson, "Rural Industry-A Traveller's View," p. 326. 